\title{
Editorial for the Special Issue on Migration, Education, and Youth
}

Ana Vila Freyer ${ }^{1}$ and Sümeyra Buran ${ }^{2}$

Youth studies is a growing area within migration scholarship. It is evident that migration of children, unaccompanied children and children within refugee flows are significantly higher than general migration flows. We have evidence of this, for example, in the case of Syrian exodus since the outbreak of civil war in the country in 2011 (Yazgan et al., 2015). KuluGlasgow et al. (2019), Vila Freyer \& Özerim (2020), and Vila Freyer and Meza Gonzalez (2021) are the recent collections of studies on youth in migration published by Transnational Press London alone. In the last couple of years, hundreds of articles and book chapters on youth migration have been published elsewhere. The Migration Conferences, Migration Letters proudly supports, have offered a venue for discussions on the topic since the beginning in 2011, and it has included a special track on youth migration to foster research in this particular topic.

It is important to highlight the significance of youth for domestic and international migration flows. The young population including children, adolescents and young adults aged up to 30 constitute nearly half of all migrants around the world (Vila Freyer \& Özerim, 2020). The weight of these young migrants, however, does not translate into theoretical perspectives despite a bourgeoning migration literature exists. To an extent, it is understandable that children and youth are often dependents and appear along with their migrating parents; however, they are also key agents in migration processes as well as in the process of settlement and integration. They are part of family strategies to reduce risks as they send remittances (see Martin, 2016; Alleluyanatha \& Treasure, 2021). They are part of integration strategies (see Carignani et al. 2020) while also being architects of building transnational spaces at schools (Simsek, 2013; Sakiz, 2016; Alkhawaldeh, 2018). We are still unclear about how these processes work, how identities are formed in diaspora (see El Berni, 2018). In this special issue, we aimed at encouraging more debates and research into various aspects of youth migration.

In this issue, we present a selection of papers discussing from a multidisciplinary perspective and referring to various geographies, the particularities of young migrants, their decisions to return, determinants of their migration, social networks, integration, education, and their role in the diaspora. Our goal is to continue the debate on youth migration and point out the questions and theoretical challenges to further our understanding of human mobility. Experiences of two young Mexican immigrant women from the US benefiting from the advance parole program visiting Mexico is the opening article in the issue. Evgenia Anastasiou draws out attention to the experiences of medical students and their migration plans during the Pandemic. Following on the same track, Kamninga and colleagues look into the role of

\footnotetext{
${ }^{1}$ Ana Vila Freyer, Universidad Latina de México, México. E-mail: ana6509@yahoo.com.

2 Sümeyra Buran, University of Florida, Department of English, United States. E-mail: sumeyra19@hotmail.com. 


\section{Editorial}

social networks in determining youth migration with a focus on entrepreneurship in Malawi. It is an important rare study looking into a small African country. Hoxha's article explains the multifaceted nature of migration determinants for the youth in a small European country, Kosovo, which is complemented by another small country study by Zulfiu Alili, King and Gedeshi with a particular interest in brain drain in North Macedonia. Chan and Hiramatsu, keeping on the same track of brain drain, delve into the dynamic nature of core-periphery relationship in skilled migration and innovation nexus. The last paper in this issue explores the fragmentation among the Palestinian youth in diaspora by Christou.

\section{References}

Alkhawaldeh, A. (2018). Syrian refugees' children instructional challenges and solutions in Jordan: teachers' and parents' perspectives. Border Crossing, 8(2), 311-331.

Alleluyanatha, E., \& Treasure, L. (2021). Effect of Youths Remittances on Rural Livelihoods in South Eastern Nigeria. Remittances Review, 6(2), 133-151.

Carignani, Ş. S., Schlimbach, T., Kmiotek-Meier, E., Diaz, C., Chorne, L. D., Vysotskaya, V., ... \& Däubler, M. (2020). Agency and Structure Revisited with Youth Responses to Gendered (Spatial) Mobilities in the EU. Border Crossing, 10(1), 61-78.

El Berni, H. M. (2018). Labor Migration in Qatar: A Study on the Identity of Second Generation Migrants. Border Crossing, 8(2SI), 479-497.

Kulu-Glasgow, I., Smit, M., \& Sirkeci, I. (Eds.) (2019). Unaccompanied children: From migration to integration. London: Transnational Press London.

Martin, P. L. (2016). Migration, trade and remittances: Low-and high-skilled workers. Remittances Review, 1(1), 37-52.

Sakiz, H. (2016). Gocmen cocuklar ve okul kulturleri: Bir butunlestirme onerisi. Goc Dergisi, 3(1), 65-81.

Simsek, D. (2013). Experiences of Turkish Cypriot, Kurdish and Turkish youth in creating transnational social spaces in London schools. Border Crossing, 3(1), 15-27.

Vila Freyer, A. and Meza Gonzalez (Eds.) (2021). Young Migrants Crossing Multiple Borders to the North. Sale: Transnational Press London.

Vila Freyer, A., \& Özerim, G. M. (2020). Young Migrants, Vulnerabilities, Bounderies, Protection, and Integration. London: Transnational Press London.

Yazgan, P., Utku, D. E., \& Sirkeci, I. (2015). Syrian Crisis and Migration. Migration Letters, 12(3), 181-192. https://doi.org/10.33182/ml.v12i3.273 